\title{
PATH ANALYSIS ON THE EFFECTS OF BIO-PSYCHOSOCIAL FACTORS AND CALORIE INTAKE IN BLOOD GLUCOSE CONTROL IN PATIENTS WITH TYPE 2 DIABETES MELLITUS
}

\author{
Isfaizah $^{1,2)}$, Bhisma Murti²), Dono Indarto3) \\ 1)Ngudi Waluyo University, Ungaran, Central Java \\ 2)Masters Program in Public Health, Sebelas Maret University \\ 3) Faculty of Medicine, Sebelas Maret University
}

\begin{abstract}
Background: Diabetes mellitus (DM) is a serious chronic disease with its tendency to deteriorate. The DM cases worldwide in 2015 was 415 million people and it is estimated to increase as many as 642 million cases in 2040. Indonesia ranked 7 in the world with 10 million cases of DM in 2015, about 90\% of which were Type 2 Diabetes Mellitus. This study aimed to determine the effect of biopsychosocial factors and calorie intake on the blood glucose control in patients with Type $2 \mathrm{DM}$.
\end{abstract}

Subjects and Method: This was an analytic and observational study with case control design. This study was carried out at Internal Medicine Polyclinic, Department of Endocrinology, Dr. Moewardi Hospital, Surakarta, Central Java, from October to November 2016. A total sample of 135 cases of Type 2 DM were selected for this study by fixed disease sampling. As many as 106 of these study subjects at HbA1c $\geq 6.5 \%$ and 29 cases of Type 2 DM had HbA1c $<6.5 \%$. The dependent variable was HbA1c level. The independent variables were educational level, family income, psychological stress, calorie intake, and Body Mass Index (BMI). The data were collected by a set of questionnaire. HbA1c was measured by High Performance Liquid Chromatography (HPLC), which was recorded in the medical record. Calorie intake was measured by 24 hour food recall. Psychological stress was measured by International Physical Activity Questionnaire (IPAQ). The data was analyzed by path analysis on STATA 13.

Results: Psychological stress $(b=0.99,95 \% \mathrm{CI}=0.07$ to $1.92, \mathrm{p}=0.034)$, calorie intake $(b=1.84,95 \% \mathrm{CI}=-0.24$ to $3.92, \mathrm{p}=0.083)$, and $\mathrm{BMI}(\mathrm{b}=1.15$, $95 \% \mathrm{CI}=0.22$ to $2.08, \mathrm{p}=0.016$ ), had positive and statistically significant effect on HbA1c. Calorie intake increased BMI $(b=2.35,95 \% \mathrm{CI}=0.31$ to 4.39 , $\mathrm{p}=0.024)$, education decreased calorie intake $(\mathrm{b}=-2.26,95 \% \mathrm{CI}=-3.38$ to $1.14, \mathrm{p}<0.001)$, and family income increased calorie intake $(\mathrm{b}=1.23,95 \% \mathrm{CI}=$ 0.26 to $2.21, \mathrm{p}=0.013$ ).

Conclusion: Calorie intake, BMI, psychologi stress, and family income are associated with increase in HbA1c level. Education decreases HbA1c level via decreased calorie intake. Type 2 DM patients need to pay attention to these biopsychosocial factors and calorie intake in order to control blood sugar.

Keywords: biopsychosocial factors, calorie intake, HbA1c

Correspondence: Isfaizah. Ngudi Waluyo University, Ungaran, Central Java. Email: is.faizah84@yahoo.com. Mobile: +6281228570003. 